\title{
European waste management experience: yesterday, today, tomorrow
}

\author{
Alfira Khaertdinova ${ }^{1, *}$, Dilbar Sultanova ${ }^{1}$, and Albert Karimov ${ }^{2}$ \\ ${ }^{1}$ Kazan National Research Technological University, Department of innovation in chemical technology, 420015, Kazan, Russia \\ ${ }^{2}$ Ministry of Industry and Trade of Republic of Tatarstan, 420111, Kazan, Russia
}

\begin{abstract}
The article presents an economic analysis of the state of municipal waste generation, utilization and recycling in the countries of the European Union and the Russian Federation. As a basis for the analysis, we used data on the 20 most representative countries that make a significant contribution to the formation of the main macroeconomic indicators of the EU. The results of the implementation of the EU environmental policy, the degree of reflection on the volume of trade in secondary raw materials, private investment in this sector, employment in the processing and recycling sectors, etc. are considered. In addition, a correlation analysis was carried out, which allowed us to determine the degree of dependence of waste disposal and recycling on various indicators, to identify the most significant of them and the main factor affecting the effectiveness of the country's environmental policy.
\end{abstract}

\section{Introduction}

In recent decades, the issue of rational and efficient use of the total amount of material goods produced in the economy in order to reduce waste generation has become more and more acute for humanity. Waste is the loss of material and energy resources [1]. The disposal of municipal waste, by storing it in landfills, is a traditional way of disposal, which has long been abandoned in many countries. Such disposal can lead to pollution and harmful effects on the environment and it does not comply with environmental regulations. For these purposes, it is necessary to adopt a comprehensive program of measures for the collection, processing, disposal, disposal of household garbage and monitor the results of these measures. The less waste generated in a country relative to the household consumption of materials used in the economy, the more successful the fight against this waste is. In Europe, which is coping well with the issue of processing all types of waste, the percentage of waste generation per household consumption is decreasing in many countries, and this is a positive trend. Although in different countries to different degrees. For example, over the past 15 years in Estonia, this indicator has decreased from $49.5 \%$ to $30.5 \%$. In Latvia from $16.2 \%$ to $7.9 \%$., in Sweden from $12.9 \%$ to $8.6 \%$. The decline in the share of waste generation over the past 15 years was $12.7 \%$ in Italy, $8.0 \%$ in Spain, and 2.6\% in France. [2].

\section{Materials and methods}

The object of the study is the development of household and industrial waste management in the countries of the European Union.

The subject of the study is the factors that determine the efficiency of waste management in the EU countries.

The solution of the tasks set in the article was carried out on the basis of the use of statistical methods of analysis. The statistical database of Eurostat was used as the research base. The dynamic series on the indicators of waste generation and disposal, value added and the number of employees in the circular economy allowed us to track the changes in these values in dynamics, to assess the degree of their discrepancies, to determine the absolute and relative differences. This gave us the opportunity to make a cross-country comparison. Correlation analysis of relationships in terms of budget allocations for R \& D, investment in human capital, education and waste disposal, etc. I identified their dependence and determined the degree of influence on the resulting indicator of the effectiveness of waste management.

\section{Results}

The intensity of waste generation is characterized by the ratio of waste generation and the level of economic development of the country. A decrease in the volume of waste per unit of GDP is an indicator that there is an increase in value added, due to a reduction in the share of industries with high material intensity. GDP is

\footnotetext{
* Corresponding author: alfira gks@mail.ru
} 
growing at the expense of industries with low material consumption, and cost reduction leads to the fact that the share of waste is also reduced [table 1]. This is a positive trend. It is observed in almost all EU countries. Some countries have made major changes in this direction over the past 15 years. Estonia, Poland, and Lithuania have almost halved this ratio. [2]

Against this background, the situation in Russia does not look the best. However, this difference is due to the accounting methodology used in Russian and European statistics. In Russia, 93\% of the generated waste is accounted for by the type of activity "mining", associated with the formation of large mineral waste, which is not included in the European accounting. [3]

Table 1. Types of technologies for the collection, sorting and recycling of polymer waste at the beginning of 2021 in the global market.

\begin{tabular}{|l|c|c|c|c|}
\hline & 2004 & 2010 & 2014 & 2018 \\
\hline $\begin{array}{l}\text { European Union - } \\
27 \text { countries }\end{array}$ & 76 & 69 & 68 & 66 \\
\hline including: & & & & \\
\hline Belgium & 104 & 109 & 92 & 99 \\
\hline Czechia & 135 & 78 & 72 & 71 \\
\hline Denmark & 35 & 44 & 40 & 37 \\
\hline Germany & 51 & 55 & 56 & 52 \\
\hline Estonia & 1066 & 772 & 728 & 646 \\
\hline Spain & 83 & 58 & 64 & 64 \\
\hline France & 49 & 49 & 46 & 46 \\
\hline Croatia & 116 & 68 & 70 & 77 \\
\hline Italy & 51 & 62 & 69 & 69 \\
\hline Lithuania & 261 & 109 & 99 & 105 \\
\hline Latvia & 73 & 74 & 97 & 58 \\
\hline Netherlands & 70 & 68 & 66 & 63 \\
\hline Austria & 86 & 54 & 51 & 50 \\
\hline Poland & 211 & 184 & 187 & 168 \\
\hline Finland & 134 & 129 & 73 & 70 \\
\hline Sweden & 73 & 49 & 46 & 49 \\
\hline United Kingdom & 91 & 56 & 55 & 58 \\
\hline Norway & 21 & 25 & 25 & 24 \\
\hline Russia* & 68 & 79.1 & 83.3 & 98.3 \\
\hline$*$ ) tons per million rubles & & & \\
\hline
\end{tabular}

In European countries, the issue of municipal waste disposal is being solved quite successfully. Figure 1 according to statistics from Eurostat shows the share of recycled waste in the total volume of municipal waste in the EU countries (average values for twenty years).

\section{The share of recycled waste in $\%$}

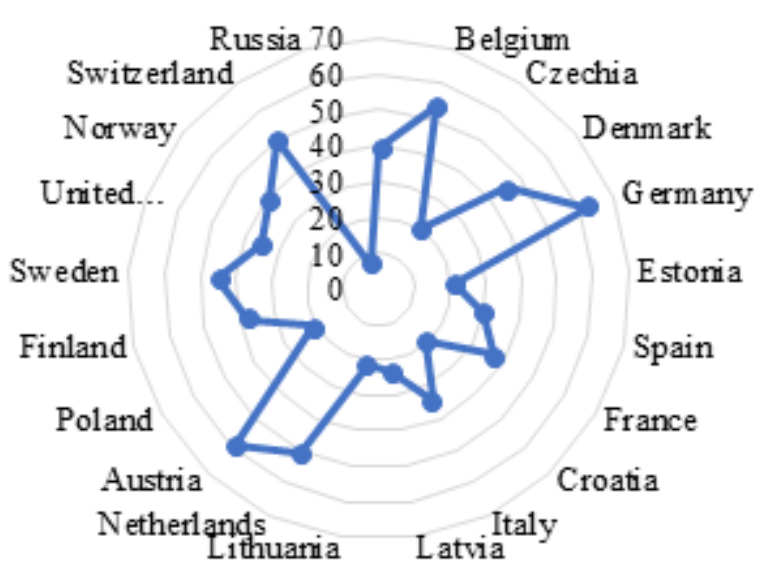

Fig. 1. Disposal of household waste.

The leaders in this issue are Germany, Austria, and Belgium. In these countries, the production of household waste per capita is quite high, 500-600 kg per capita, but the share of recycled waste here is one of the highest and is about $60 \%$. This indicates the existence of strict environmental standards in these countries in the field of household waste recycling. [2]

The existence of a legal framework, current standards, a course towards a circular economy, and the desire to minimize waste generation over time bears fruit [4]. The level of income of the population has an impact on the waste management in the country. However, in high-income countries, there is no equality between the amount of waste produced and the amount of waste disposed of. The balance is achieved in middle-income countries, i.e. the service-to-income ratio is directly related. Public payments for waste management in the leading EU countries significantly exceed the amount of payments in other countries of the world. Relative to Russia - this excess is up to 10 times $[5,6]$.

Other countries of the European Union are also increasing the degree of recycling. Over the past six years, Croatia, Lithuania (136.0\%), the Czech Republic $(120 \%)$, and Finland (112.1\%) have made significant progress. It is obvious that in countries with high urbanization and population density $(75 \%$ of the population lives in cities), the burden on public services increases [2].

China's refusal to export plastic waste has made it more difficult to solve the problem of its disposal. Incineration or burial is not the best solution. Recycling of garbage, using garbage as a secondary raw material and using it as an alternative resource the transition to a closed-cycle economy is a reasonable way, but not the cheapest $[7,8]$. Waste should remain in the business cycle for as long as possible. This requires new technologies for deep waste processing, which means additional allocations for the development of such technologies.

It is a well-known fact that the circular economy contributes to job creation and economic growth. The 
fact of maintaining the course of the circular economy in the old world is manifested in the volume of value added related to the closed-cycle economy sector, as well as the number of people employed in these sectors [9]. This includes those employed in the recycling, recycling, repair and reuse sectors. As can be seen from the diagram below (Fig. 2) over the past seven years (20102017), the growth of value added and the accompanying growth in the number of industries in the circular economy has shown positive dynamics in almost all countries, which once again confirms our hypothesis that the issue of waste recycling in the EU countries is successfully solved through the recycling of solid municipal waste [2].

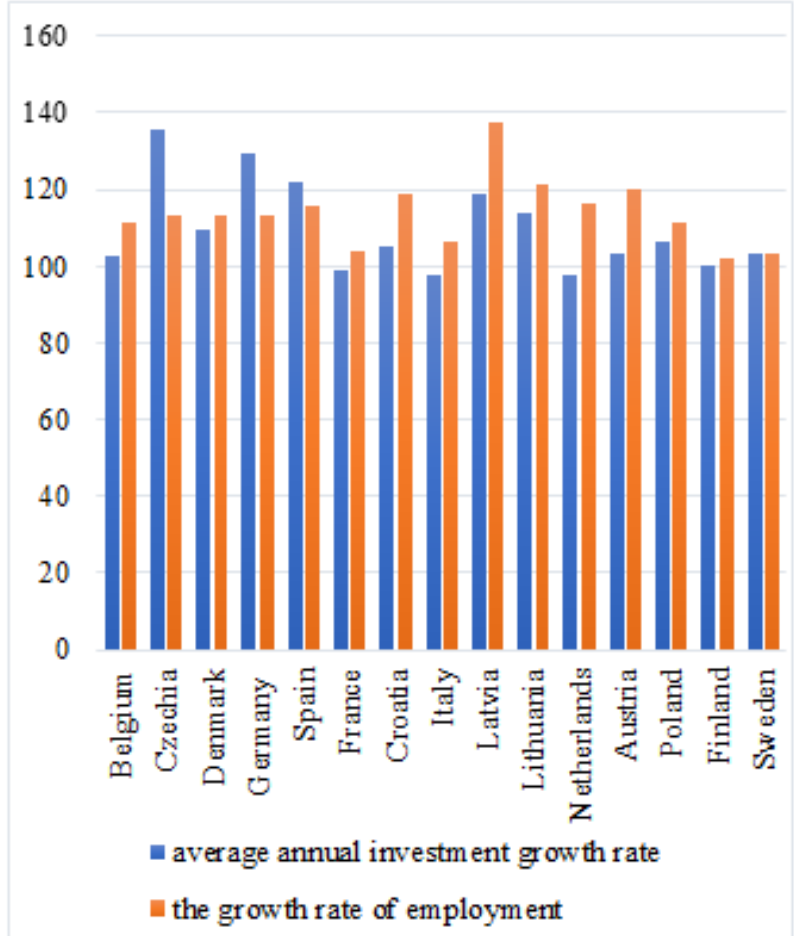

Fig. 2. Dynamics of the growth rate of value added and the number of employees in the circular economy sectors for 20102018 , in $\%$.

The transition to a circular economy is the way to a high-tech economy. It will allow you to extract secondary raw materials from municipal garbage, give them a second life and use the selected waste in the form of alternative resources [10]. The vast majority of household waste is packaging. The idea of using an environmentally friendly material for packaging goods requires incentives for manufacturing enterprises [11]. In European countries, "Packaging Registry Centers" are being established to coordinate the work of enterprises to achieve targets for improving the quality of packaging material. [12-13].

In the EU countries, there is also a good practice of using secondary raw materials for the production of goods. Clothing made from recycled textiles, recycling of polymers for the production of goods for various household and industrial needs

In general, the volume of sales of secondary raw materials in the European Union does not have a significant increase. In 2019, the growth rate was $80.6 \%$ compared to 2005 and already $95.8 \%$ compared to 2018 . However, in the context of states, the picture is very contradictory. As you can see in Figure 3 for individual countries in 2019, compared to the previous year, growth reaches $395 \%$ in Poland, $200 \%$ in Croatia, $173.6 \%$ in Lithuania, and $165 \%$ in the Netherland [2].

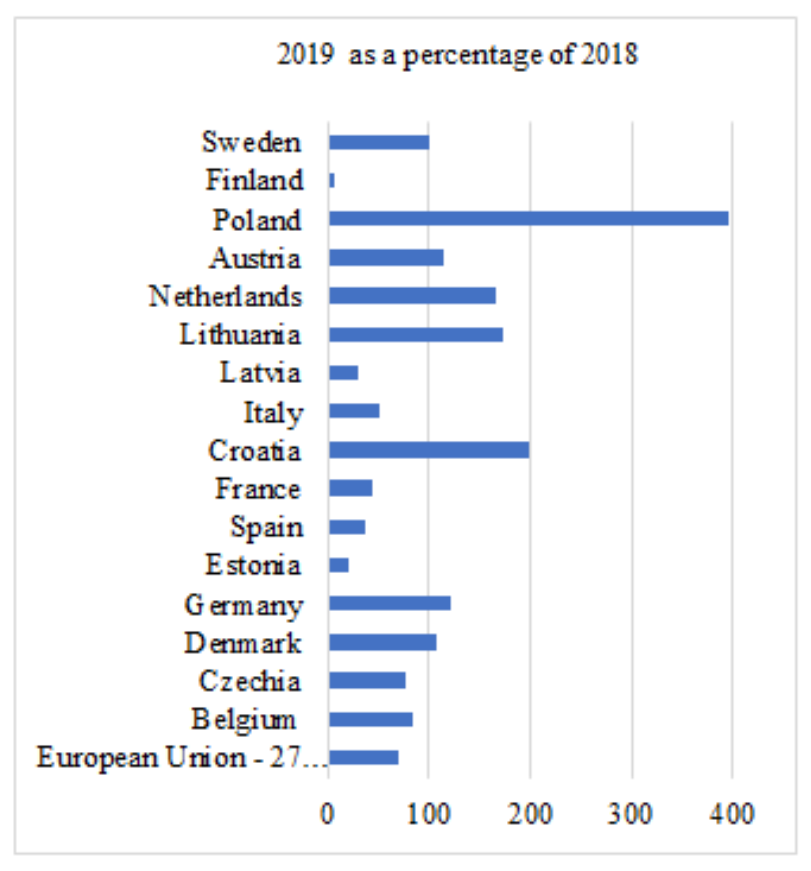

Fig. 3. Trade in processed raw materials as a percentage of the previous year

In Austria and Sweden, the volume of materials that are recycled and re-introduced into the economy as new raw materials has remained unchanged over the past 15 years. This is evidence of a well-built and stable system of waste processing and disposal.

In Finland and Italy, the volume of recycling of secondary materials tends to decrease. In Finland, a large proportion of waste is incinerated $(58 \%)$. In this way, Finland generates electricity and heat. In Italy, according to ISTAT (National Institute of Statistics), in 2019 the volume of industrial production decreased by $4.2 \%$, the level of GDP by $-5 \%$, retail sales decreased by $8.1 \%$, i.e. the overall decline in the level of economic development affected [15].

The global pandemic has affected the formation of household plastic waste. The return to the use of disposable dishes, gloves and masks contributes to the formation of an additional amount of garbage. This will affect waste generation and will be reflected in the statistics accounting for 2000-2021 [17]. be reflected in the statistical.

The introduction of a "circular economy", careful sorting of food waste, paper, glass and plastic in a modern container system for separate garbage collection is the only right way and the main priority in the state's environmental policy.

In order to study the factors that determine the effectiveness of waste management, we conducted a correlation analysis. The indicators that were used as the 
basis for the analysis were the indicators of the formation, utilization and recycling of household waste.

As a hypothesis, the following provisions were put forward:

- H1 the higher the country's GDP level, the better the waste management performance.

- H2. The higher the country's investment in GBARD, the more efficient the recycling of waste and the better developed the recycling process.

- H3. The higher the investment in human capital, the more efficient is the process of separate waste collection and, accordingly, waste recycling.

- H4. The higher the population density of a country, the more concerned it is about the environment and the more garbage per person and the higher the growth rate of garbage recycling [18].

\section{Discussion}

The hypothesis about the relationships between the variables that characterize the process of waste generation, processing, and disposal and the selected socio-economic indicators was tested by means of a correlation analysis. Table 2 shows the results of this analysis. Correlation studies were conducted based on data for 2010 -2019 for 20 leading EU countries.

Table 2. Matrix of paired correlation coefficients.

\begin{tabular}{|l|c|c|c|c|c|}
\hline & GDP & $\begin{array}{c}\text { Trade } \\
\text { turnov } \\
\mathrm{er}\end{array}$ & $\begin{array}{c}\text { Popula } \\
\text { tion } \\
\text { density }\end{array}$ & $\begin{array}{c}\text { Budge } \\
\mathrm{t} \\
\text { allocat } \\
\text { ions } \\
\text { GBA } \\
\text { RD }\end{array}$ & $\begin{array}{c}\text { Invest } \\
\text { ment } \\
\text { in } \\
\text { human } \\
\text { capital }\end{array}$ \\
\hline Education & -0.370 & 0.001 & -0.026 & 0.597 & 0.215 \\
\hline Disposal & -0.581 & 0.211 & 0.530 & 0.334 & 0.329 \\
\hline Recycling & -0.337 & 0.117 & 0.617 & 0.102 & 0.230 \\
\hline
\end{tabular}

As can be seen from the table. 2 sustainable links between education, waste and budget allocations for GBARD are identified the coefficient was 0.597131. It follows that the higher the country's GDP, the higher the GBARD costs. However, high GDP also contributes to the growth of waste. Waste management and recycling is a knowledge-intensive and expensive process that requires additional resources, which was confirmed by the analysis. A stable relationship with the indicator of GBARD costs is confirmed by studies of other authors. According to the regression model, the higher the GBARD costs, the more polymer recycling technologies are available [19].

Population density significantly affects both the development of recycling and the development of recycling ( $\mathrm{k}-\mathrm{t} 0.616961)$. With a high population density in cities, recycling and recycling of waste in the form of recycling, recycling of garbage is more developed.

The feedback in the correlation analysis with the GDP indicator is explained by the high share of value added in manufacturing industries.

\section{Conclusions}

Thus, the analysis suggests that the effectiveness of the country's environmental policy is determined by investments in the social sphere, the indicator of which is investment in human capital and in GBARD.

The conducted research and study of the issues of household waste disposal in Europe is considered by us as a model of recycling process management. In Europe, there is a lot of experience in organizing the process of municipal waste management, borrowing which can be useful for the Russian economy. In Russia, the process of collecting, recycling and recycling of household garbage is very acute. The volume of waste produced per capita is close to European, but the methods of collection, disposal and recycling leave much to be desired.

The conducted research and study of the issues of household waste disposal in Europe is considered by us as a model of recycling process management. In Europe, there is a lot of experience in organizing the process of municipal waste management, borrowing which can be useful for the Russian economy. In Russia, the process of collecting, recycling and recycling of household garbage is very acute. The volume of waste produced per capita is close to European, but the methods of collection, disposal and recycling leave much to be desired.

In 2018, more than 70 million tons of garbage were generated. This figure does not take into account waste from extractive industries. We are talking only about solid household waste, about what is thrown into the tanks by citizens, shops, offices. At the same time, no more than 5 million tons are processed. This is an unacceptably low level of waste recycling.

Since January 1, 2019, the "garbage reform" has started in Russia. It is planned to introduce separate waste collection, and solve issues related to the collection and disposal of household garbage.

By the end of 2030, 25 waste incineration plants using the Hitachi Zosen INOVA technology will be built in major Russian cities. These plants are not the initial, but the final link in the chain of garbage collection and disposal. Taking into account the foreign experience of organizing separate collection, sorting and processing of elements suitable for reuse will be carried out. Glass, metal, and waste paper must find a second life. The remaining part will be used for incineration and will be a source of energy. Producing energy from garbage isn't a panacea, but it's better than sending it to a landfill and waiting decades for it to decompose. The construction of plants for this purpose will allow you to clear huge landfills of garbage, reduce the number of landfills, which are currently comparable to the size of some European countries.

\section{References}

1. V.I. Gel, V.A. Litvinov, Modern methods of utilizing Municipal Solid Waste (MSW), IOP Conference Series: Earth and Environmental Science, 613 (1), 012038 (2020) 
2. Eurostat database [Electronic resource] Available at: https://ec.europa.eu/Eurostat/

3. Statistical collection, Industry in Russia [Electronic resource], Rosstat, (2019) Available at: www.gks.ru

4. A. Starodubova, Ch. Misbakhova, N. Gareeva, The role of quality standards for chemical products existing on the markets of the European Union in development of innovative entrepreneurship, E3S Web of Conferences: ICEPP 2020, 161, (2020)

5. A. Starodubova, D. Sultanova, A. Karimov, The concept of balanced development of waste management, E3S Web of Conferences: ICEPP 2020, $161(2020)$

6. B.R. Barros, Review of municipal waste management charging methods in different countries, R.T.D.V., Waste Management, 115, 47-55 (2020)

7. G. Halkos, K.N. Petrou, The relationship between MSW and education: WKC evidence from 25 OECD countriesn, Waste Management, 114, 240-252 (2020)

8. A. Maalouf, A. Mavropoulos, Global municipal solid waste infrastructure: Delivery and forecast of uncontrolled disposal El-Fadel, Waste Management and Research, 38 (9), 1028-1036 (2020)

9. B.N. Kulkarni, V. Anantharama, Repercussions of COVID-19 pandemic on municipal solid waste management: Challenges and opportunities, Open access, Science of the Total Environment, 743, 140693 (2020)

10. S. Venkata Mohan, S. Varjani, D. Pant, M. Sauer, Circular bioeconomy approaches for sustainability Chang, J.-S., Bioresource Technology, 318, 124084 (2020)

11. P.R. Yaashikaa, P.S. Kumar, A. Saravanan, S. Varjani, R. Ramamurthy, Bioconversion of municipal solid waste into bio-based products: A review on valorisation and sustainable approach for circular bioeconomy, Science of the Total Environment, 748, 141312 (2020)

12. É. Madushele, N. Adelard, L. Municipal, Solid Wastes Characterisation and Waste Management Strategy Evaluation in Insular Context: A Case Study in Reunion Island Lebon, Waste and Biomass Valorization (2020)

13. P. Brancoli, K. Bolton, M. Eriksson, Environmental impacts of waste management and valorisation pathways for surplus bread in Sweden, Open access, Waste Management, 117, 136-145 (2020)

14. I. Krzywnicka, K. Pawlewicz, A. Senetra, The evaluation of municipal waste in counties in poland with the use of the theory of phenomena spatial concentration, International Journal of Environmental Research and Public Health, 17 (23), 9107, 1-17 (2020)

15. P. Kaszycki, M. Głodniok, P. Petryszak, Towards a bio-based circular economy in organic waste management and wastewater treatment - The Polish perspective, New Biotechnology, 61, 80-89 (2021)

16. Istat database [Electronic resource] Available at: https://www.istat.it/en/industry-and-construction, https://www.istat.it/en/services\$

17. B.N. Kulkarni, V. Anantharama, Repercussions of COVID-19 pandemic on municipal solid waste management: Challenges and opportunities, Open access, Science of the Total Environment, 743, 140693 (2020)

18. A. Khaertdinova, D. Sultanova, D. Iskhakova, A. Karimov, Recycling of Polymers - An Opportunity or a Threat to the Economy?, E3S Web of Conferences: ICEPP 2020, 161 (2020)
19. D. Sultanova, A. Maliashova, L. Abzalilova, R Sultanova, The main obstacles for development of international activity with russian-european chemical clusters: environ-mental aspect, E3S Web of Conferences: ICEPP 2020, 161 (2020)

20. B.R. Alzamora, Waste pickers organizations and municipal selective waste collection: Review of municipal waste management charging methods in different countries Barros, R.T.D.V., Waste Management, 115, 47-55 (2020). 